\title{
Slik kan helsesykepleiere avdekke vold og overgrep
}

\section{Mange helsesykepleiere synes det er vanskelig å snakke om vold og overgrep, og flere lar være å ta opp temaet med foreldrene.}

Mariann Nicolaisen Gaathaug

Helsesykepleier

Forebyggende helsetjeneste, Skien kommune

Vold Overgrep Skolehelsetjeneste

Sykepleien 2020108 (79899) (e-79899)

DOI: 10.4220/Sykepleiens.2020.79899

\section{Hovedbudskap}

Forskning viser at både barn og voksne synes vold og overgrep kan være vanskelig å snakke om. Barn ønsker en anledning til å fortelle og få direkte og tydelige spørsmål. Helsesykepleiere opplever å ha manglende kompetanse på området samt at de er usikre på hvordan temaene kan tas opp. Hensikten med artikkelen er å belyse hva som kan påvirke helsesykepleieres arbeid med å avdekke vold og overgrep i helsesamtalen på 1. trinn.

Hvert år utsettes 1,7 milliarder av verdens barn for vold og overgrep. Dette tilsvarer tre av fire barn (1). I Norge har ett av fem barn opplevd fysisk vold, ofte gjentatte ganger. Mindre alvorlige former for vold rammer ett av tre barn. I tillegg utsettes 15 prosent av alle barn for seksuelle overgrep i løpet av barndommen (2). 
Ifølge FNs barnekonvensjon artikkel 19, skal alle barn beskyttes mot fysisk og psykisk vold, skade og misbruk (3). At barn blir utsatt for vold og overgrep skaper store kostnader for det norske samfunn, og kan gi betydelige problemer og utfordringer for den som rammes (4).

Nasjonal faglig retningslinje for det helsefremmende og forebyggende arbeidet i helsestasjon, skolehelsetjeneste og helsestasjon for ungdom gir en sterk anbefaling om at vold og overgrep er temaer som helsesykepleiere bør ta opp i helsesamtalen på 1. trinn (2).

\section{Hensikten med artikkelen}

Fagartikkelen er basert på en avsluttende fordypningsoppgave på helsesykepleierutdanningen ved universitetet i SørøstNorge. Hensikten med denne artikkelen er å belyse hva som kan påvirke helsesykepleiers arbeid med å avdekke vold og overgrep i helsesamtalen på 1. trinn.

Det er foretatt et systematisk litteraturs $\varnothing \mathrm{k}$ i databasene PubMed, SveMed og Ovid, hvor fire forskningsartikler ble valgt ut som grunnlag for oppgaven. To av artiklene tar for seg vold og overgrep fra barnets perspektiv, og to artikler belyser helsesykepleieres perspektiv i arbeid med vold og overgrep.

\section{Hva er vold?}

Begrepet vold kan forstås på flere måter, og det finnes ulike definisjoner av begrepet. Ifølge Isdal, referert av Lillevik (5), kan vold sies å være: «[...] enhver handling rettet mot en annen person, som gjennom at denne handlingen skader, smerter, skremmer eller krenker, får denne personen til å gjøre noe mot sin vilje eller slutte å gjøre noe den vil».

Denne definisjonen retter seg mot personens subjektive opplevelse av vold, og ikke objektive beskrivelser. Med en slik forståelse vil man rette søkelyset mot barnets opplevelse av situasjonen. Definisjonsmakten vil dermed overføres til barnet fremfor den som utøver volden. Å benytte denne definisjonen vil bidra til å favne om voldens kompleksitet. Ved å rette søkelyset mot barnets subjektive opplevelse kan man få en bedre forståelse for barnets livskvalitet, og derav ulike utfordringer som kan oppstå (5). 


\section{Alle bør få tilbud om helsesamtale}

Ifølge Nasjonal faglig retningslinje for helsestasjons- og skolehelsetjenesten (2) bør alle barn få tilbud om en skolestartunders $\varnothing$ kelse på 1. trinn. Som en del av denne unders $\varnothing$ kelsen bør det tilbys helsesamtale hos helsesykepleier. Hensikten med helsesamtalen er å opprette kontakt med barn og foreldre og å skape et utgangspunkt for videre samarbeid for å ivareta barnets behov.

Et viktig poeng i helsesykepleiers arbeid er primært å ivareta barnet, og ikke foreldrene (6). Å stille spørsmål om vold og overgrep som rutine til alle, kan bidra til å identifisere utsatte barn. Det er viktig at helsesykepleier er bevisst på helsesamtalen som kontekst, og hvordan den virker inn på barnet og foreldrene. Det som observeres i situasjonen trenger ikke nødvendigvis å reflektere omsorgen som gis i hjemmet (7).

\section{Hvordan bør vi snakke om overgrep?}

Dersom helsesykepleier får mistanke om at et barn er utsatt for vold eller overgrep anbefaler Alsaker (8) at man bør fors $\varnothing$ ke å nærme seg tematikken ved å være åpen og direkte. Han mener at vold og overgrep kan sees som et symptom på krise, hvor foreldrene ikke mestrer situasjonen de står i. Det er derfor viktig å ikke være dømmende. Å stille spørsmål som viser forståelse og empati kan gi rom for samarbeid med familien.

\section{三 «Det er viktig å ikke være dømmende.»}

Det anbefales at helsesykepleier kan stille spørsmål til barnet som: «Jeg har inntrykk av at det er noe som plager deg. Er det noe som det er vanskelig for deg å fortelle om?» (8). Til foreldrene kan helsesykepleier stille spørsmål som: «Dette er symptomer som vi ikke sjelden ser hos barn som er blitt utsatt for overgrep. Er det mulig at noen kan ha skadet barnet ditt?» (8).

Helsesykepleier bør avklare med foreldrene om de deler den samme bekymringen. Be foreldrene om en forklaring, og om de ser noen sammenheng i dette. Å være konkret i samtalen, uten å være opptatt av årsaken, kan være til hjelp i arbeidet (2).

Videre sier Markestad (9) at helsesykepleiere kan konkretisere for barnet og stille spørsmål som: 
«[...] barn kan få vondt i magen dersom noen er slemme og slår, eller er ekle og tar på kroppen på steder barn synes er veldig dumt, kanskje på rumpa eller tissen, eller at de tvinger barn til å gjøre ekle ting. Det kan være store gutter eller menn eller andre, og det hender også at det skjer hjemme. Er det noen som har vært slik mot deg?»

Slike spørsmål kan stilles til barnet med foreldrene til stede. Det sender et signal om at foreldre og helsepersonell bør være oppmerksom på problematikken (9). Gjennom åpen dialog med foreldrene kan man dele bekymring for barnets situasjon (8).

\section{Kunnskap gjør oss tryggere}

Erfaringer fra praksis viser at mange helsesykepleiere synes temaene vold og overgrep er vanskelige å snakke om. Albaek, Kinn og Milde (10) presenterer et tilsvarende bilde av nettopp dette, hvor usikkerhet om hvordan og når man skal stille spørsmål rettet mot vold og overgrep blir trukket frem. Deres artikkel viser at helsesykepleierne ikke var forberedt på svarene de kunne få, og de var usikre på hvordan de skulle reagere i situasjonen.

Helsesykepleiere kan føle skam, skyld og frustrasjon, og bli fortvilte, når de snakker med foreldre om vold og overgrep $(10,11)$. Flere velger derfor å unngå temaene, eller distansere seg fra dem. Begge studiene viser at mange helsesykepleiere brukte vage og diffuse formuleringer, og de var lite konkrete i samtalen med barn og foreldre.

Brattfjell og Flåm (12) finner at barn ønsker direkte og åpne spørsmål. At helsesykepleiere tar avstand fra temaene kan sees som en motsetning til nettopp dette. Med en slik tankegang kan helsesykepleiers egne følelser komme i konflikt med arbeidet om å avdekke vold og overgrep. Som deltakerne i studien til Albaek, Kinn og Minde (10) selv uttalte, var ferdigheter i å håndtere egne følelser viktig, og erfaring bidro til å minske frykten deres.

Erfaring fra praksis viser også at helsesykepleiere ble tryggere i situasjonen etter hvert som de fikk mer kompetanse på området, men at de var usikre på hva de skulle gjøre med svarene de fikk.

\section{三 «De var usikre på hva de skulle gjøre med svarene de fikk.»}


I arbeid med andre mennesker er det viktig å kjenne seg selv godt (13). Det handler om egne erfaringer og betydningen av disse. Hvilken forforståelse man har, ens verdisyn og personlighet påvirker helsesykepleierrollen og hvordan man reagerer i ulike situasjoner. Det er nettopp gjennom et bevisst forhold til forforståelse, verdisyn og personlighet at man kan utnytte sine egne ressurser, og dermed ivareta barn og foreldre på en god måte (13).

Brattfjell og Flåm (12) trekker frem at en god dialog mellom barn, foreldre og helsesykepleiere er viktig for å avdekke vold. Helsesykepleiers kommunikasjon med barn og foreldre kan derfor sees som relevant i denne sammenhengen.

Barn som har vært utsatt for vold og overgrep har uttalt at de trengte en anledning til å fortelle. I helsesamtalen vil det dermed være viktig for helsesykepleier å stille direkte, åpne spørsmål, og ha mot til å stå i situasjonen uavhengig av svarene som gis.

\section{Lytt til barna}

Mangel på kunnskap om vold og overgrep mot barn kan sees som et hinder i avdekkingsprosessen (12). Noen barn vet kanskje ikke at det er vold eller overgrep de er utsatt for.

På den andre siden kan barn oppleve en situasjon annerledes enn den voksne. Med utgangspunkt i Isdal sin definisjon av vold, hvor barnets subjektive opplevelse står i sentrum, bør helsesykepleier lytte til barnets historie. Dette gir barnet definisjonsmakt over situasjonen, uten at det nødvendigvis er den objektive sannheten som blir presentert.

\section{三 «Foreldre har blitt overrasket når de har hørt barnets historie.»}

Gjennom praksis har det vist seg at foreldre har blitt overrasket når de har hørt barnets historie, og hvordan barnet har fortolket den (12). Helsesykepleiers rolle handler først og fremst om å ivareta barnet (6). Det kan tolkes som at barnets perspektiv bør være det viktigste, for å skape trygghet og tillit i relasjonen. 
Forskningen til Jensen og medarbeidere (14) viser at barn mangler anledninger til å fortelle om sine opplevelser. Barn som har vært utsatt for vold og overgrep ga hint og tegn gjennom barndommen i håp om at noen skulle forstå (12). Når man samtidig vet at symptomer på vold og overgrep kan være diffuse, kan dette skape utfordring i helsesykepleiers arbeid (8). Helsesykepleier kan aldri vite nøyaktig hva den andre fors $\emptyset$ ker å formidle (15).

Å kjenne til risikofaktorer hos både barn og foreldre, og å kunne reflektere over disse, kan sees som et godt utgangspunkt for helsesamtalen. Å ha en felles forståelse og referanse til temaene vold og overgrep er sentralt (14).

Når vold og overgrep er temaer det snakkes lite om, er det naturlig å tenke seg at både barn og voksne synes det kan være utfordrende med direkte beskrivelser av hva de har opplevd. Helsesamtalen kan i denne sammenheng sees som en god mulighet for helsesykepleier til å bidra med kunnskap til familien.

\section{Barn er redd for å ødelegge relasjoner}

Felles for alle de inkluderte studiene er at de handler om familierelasjoner. Barneperspektivene presenterer et bilde hvor barna er redd for å ødelegge relasjoner innad i familien dersom de forteller om hva de har opplevd, og de er redd for ikke å bli trodd. I studien til Brattfjell og Flåm (12) var også trusler fra overgriperen en årsak til at volden ikke ble avdekket, og barna var redd for å oppleve skyld, skam og frykt dersom de valgte å si noe.

Fra helsesykepleiernes perspektiv kommer også redsel for å $\varnothing$ delegge relasjoner i familien frem. Helsesykepleierne hadde liten tro på at de kunne hjelpe barna til en bedre situasjon dersom vold og overgrep ble avdekket, og de opplevde at barna var lojale mot foreldrene sine. Dette viser et komplekst bilde av helsesykepleieres utfordringer.

\section{三 «Helsesykepleierne hadde liten tro på at de kunne hjelpe barna dersom vold og overgrep ble avdekket.»}


Tilnærmingen til temaene vold og overgrep i helsesamtalen blir dermed vesentlig. Hvordan samtalen skal foregå, må avgjøres i hvert enkelt tilfelle, viser Nasjonal faglig retningslinje (2). Som tidligere nevnt er det å stille åpne og direkte spørsmål viktig. Markestad (9) mener at spørsmålene kan rettes til barnet med foreldrene til stede. Når barn og foreldre møter sammen til konsultasjonen, får helsesykepleier mulighet til å dele sin bekymring for barnets situasjon.

Helsedirektoratet (2) legger vekt på at helsesykepleierne skal være direkte i samtalen, uten nødvendigvis å rette s $\varnothing$ kelyset mot årsaksforklaringer.

Når en person som skal beskytte og gi omsorg til et barn utsetter barnet for skade, kan dette bidra til en negativ utvikling av barnets helse (16).

I studien til Brattfjell og Flåm (12) var det å stole på personen man valgte å fortelle til viktig. Hvis et barn sitter ved siden av voldsutøveren, samtidig som helsesykepleier og en eventuell lege stiller direkte spørsmål, kan det tenkes at dette oppleves som utfordrende for både barn og foreldre. Det blir derfor viktig at helsesykepleier informerer om hvilken hjelp familien kan få, både fra skolehelsetjenesten og andre instanser.

Helsesykepleier bør også støtte barnet ved å informere om muligheten til å oppsøke helsesykepleier senere (2).

\section{Helsesykepleieren kan hjelpe barnet}

Gjennom helsesykepleierrollen følger en forventning om kompetanse, myndighet og makt. Selv om helsesykepleieren ikke opplever å være i en maktposisjon, kan det likevel oppleves slik for barn og foreldre (17). Makt er et begrep som lett kan sees som noe negativt, og knyttes til undertrykkelse og dominans.

På motsatt side kan det sees som en mulighet, ved at man har makt til å utrette noe.

Ifølge den franske filosofen Foucault (1926-1984) finnes makt overalt, og sees i all menneskelig handling. Han ser kunnskap og makt som to nære begreper som gjør seg gjeldende for eksempel i møte mellom helsesykepleier, barn og foreldre (17). Det viser at det utspiller seg en maktsituasjon i helsesamtalen, hvor partene har ulike roller. Helsesykepleiere har makt gjennom sin profesjon og kunnskap om vold og overgrep. Barn og foreldre har kunnskap om sin situasjon, og velger selv hva de vil dele i samtalen. 


\section{$\equiv$ ¿Helsesykepleiere har makt gjennom sin profesjon og kunnskap om vold og overgrep.»}

Forskning viser at noen barn som har vært utsatt for vold og overgrep er redd for trusler fra overgriperen (12). Barn er ofte lojale mot foreldrene sine til tross for hva de er utsatt for (11). Foreldre og barn har et asymmetrisk maktforhold, hvor den voksne har makt over barnet gjennom sin rolle som omsorgsperson. De har mulighet til å påvirke barnet, og barnet er avhengig av at dette ikke gjøres på en måte som krenker eller skader det (5). Det asymmetriske maktforholdet kan derfor innvirke på maktbalansen i dialogen.

Kan helsesamtalens organisering og hvem som er til stede påvirke helsesykepleiers arbeid med å avdekke vold og overgrep?

Ifølge nasjonalfaglig retningslinje (2) kan helsesykepleier og lege selv velge om de skal gjennomføre konsultasjonen sammen eller hver for seg. Sees dette i lys av Foucault sin teori om kunnskap og makt, er det viktig at skolehelsetjenesten er bevisst på hvordan maktforhold kan utspille seg i helsesamtalen. Det kan derfor tenkes at det å møte helsesykepleier og lege sammen til skolestartunders $\varnothing$ kelsen kan virke overveldende for familien, og derav skape større ubalanse i maktforholdet enn om familien møtte helsesykepleier og lege hver for seg.

Samtidig er helsedirektoratet opptatt av at helsesamtalen og legeunders $\varnothing$ kelsen b $\varnothing$ r sees i sammenheng, og et samarbeid blir derfor sentralt, uavhengig av konsultasjonens organisering (2).

\section{三 «Det er den voksnes ansvar å bringe temaet på bane.»}

Som omtalt kan makt forstås som et omfattende begrep med ulike dimensjoner. Dette viser maktens dualitet som på den ene siden kan påvirke barn negativ, mens det på den andre siden kan gi muligheter til å hjelpe dem. Ved å rette oppmerksomheten mot barnets opplevelse av situasjonen overfører man dermed definisjonsmakten til barnet (5). I dette arbeidet er det derfor viktig å se den enkelte.

Helsesykepleier må våge å tro at barn faktisk utsettes for vold og overgrep. Det er den voksnes ansvar å bringe temaet på bane, ved å bry seg og tørre å spørre, og dermed skape mulighet til å hjelpe barn og foreldre (18). 


\section{Konklusjon}

Artikkelen viser et komplekst bilde av helsesykepleieres arbeid. A tørre å stille de direkte spørsmålene, og ta imot svarene som kommer kan skape mulighet til å avdekke vold og overgrep.

Barn $\varnothing$ nsker en anledning til å fortelle om sine opplevelser. $\AA$ legge vekt på barnets subjektive opplevelse kan bidra til en mer åpen og sammensatt forståelse for situasjonen, og hvordan dette påvirker barnets livskvalitet. Helsesykepleiere er derfor avhengig av kompetanse om vold og overgrep, og hvordan de kan snakke med barn og voksne om temaene. $\AA$ legge vekt på opplæring, implementering av nye anbefalinger og rom for faglige diskusjoner kan sammen bidra til økt trygghet.

Helsesykepleiere må tørre å sette temaene på dagsordenen, og vise barn og foreldre at vold og overgrep kan snakkes om.

\section{Referanser}

1. Know Violence in Childhood. Ending Violence in Childhood: Global Report 2017. New Delhi: Know Violence In Childhood; 2017. Tilgjengelig fra:

http://globalreport.knowviolenceinchildhood.org/ (nedlastet 15.08.2019).

2. Helsedirektoratet. Nasjonal faglig retningslinje i det helsefremmende og forebyggende arbeidet i helsestasjon, skolehelsetjeneste og helsestasjon for ungdom.

Helsedirektoratet; 2017. Tilgjengelig fra: https://helsedirektoratet.no/retningslinjer/helsestasjons-ogskolehelsetjenesten (nedlastet 15.08.2019).

3. FNs generalforsamling. Konvensjon om barns rettigheter. Forente Nasjoner; 20 november 1989. Lovsamlingen vol. 1577. Tilgjengelig fra: https://www.refworld.org/docid/3ae6b38fo.html (nedlastet 15.08.2019).

4. Meld. St. 12 S (2016-2017). Opptrappingsplan mot vold og overgrep (2017-2021). Oslo: Barne- og likestillingsdepartementet; 2016. Tilgjengelig fra: https://www.regjeringen.no/no/dokumenter/prop.-12-s20162017/id2517407/ (nedlastet 15.08.2019). 
5. Lillevik OG. Perspektiver på vold mot barn. I: Mevik K, Lillevik OG, Edvardsen O, red. Vold mot barn - teoretiske, juridiske og praktiske tilnærminger. 1. utg. Oslo: Gyldendal Norsk Forlag; 2016. s. 17-37.

6. Viljugrein T, Lindboe A. Helsestasjonen - de yngste barnas rett til helsetjeneste. I: Holme H, Olavesen ES, Valla L, Hansen MB, red. Helsestasjonstjenesten - Barns psykiske helse og utvikling. 1. utg. Oslo: Gyldendal Norsk Forlag; 2016. s. $19-26$.

7. Braarud HC, Nordanger D $\varnothing$. Når vold og overgrep infiltrerer omsorgen for små barn. I: Holme H, Olavesen ES, Valla L, Hansen MB, red. Helsestasjonstjenesten - Barns psykiske helse og utvikling. 1. utg. Oslo: Gyldendal Norsk Forlag; 2016. s. 139-50.

8. Alsaker T. Miljøbetingede skader og sykdommer. I: Markestad T, red. Klinisk pediatri. 3. utg. Bergen: Vigmostad og Bjørke; 2016. s. 411-24.

9. Markestad T. Anamnese og klinisk unders $\varnothing$ kelse. I: Markestad T, red. Klinisk pediatri. 3. utg. Bergen: Vigmostad og Bjørke; 2016. s. 7-15.

10. Albaek AU, Kinn LG, Milde AM. Walking children through a minefield: How professionals experience exploring adverse childhood experiences. Qualitative Health Research. 2018;28(2):231-44. DOI: 10.1177/1049732317734828

11. Kraft LE, Rahm GB, Eriksson U-B. School nurses avoid addressing child sexual abuse. The Journal of School Nursing. 2017;33(2):133-42. DOI: 10.1177/1059840516633729

12. Brattfjell ML, Flåm AM. «They were the ones that saw me and listened.» From child sexual abuse to disclosure: Adults'recalls of the process towards final disclosure. Child Abuse Negl. 2019;89:225-36. DOI: 10.1016/j.chiabu.2018.11.022

13. Røkenes $\mathrm{OH}$, Hanssen P-H. Bære eller briste Kommunikasjon og relasjon i arbeid med mennesker. 3. utg. Bergen: Fagbokforlaget; 2012.

14. Jensen TK, Gulbrandsen W, Mossige S, Reichelt S, Tjersland OA. Reporting possible sexual abuse: A qualitative study on children's perspectives and the context for disclosure. Child Abuse Negl. 2005;29(12):1395-413.

DOI: $10.1016 /$ j.chiabu.2005.07.004 
15. Eide H, Eide T. Kommunikasjon i relasjoner:

personorientering, samhandling, etikk. 3. utg. Oslo: Gyldendal

Norsk Forlag; 2017.

16. Skjørten K, Hauge M-I, Langballe Å, Schultz J-H, $\emptyset$ verlien C. Å se det utsatte barnet. I: Hauge M-I, Schultz J-H, $\varnothing$ verlien C, red. Barn, vold og traumer: Møter med unge i utsatte livssituasjoner. 1. utg. Oslo: Universitetsforlaget; 2016. s. $93-107$.

17. Tveiten S. Helsepedagogikk: pasient- og pårørendeopplæring. 1. utg. Bergen: Vigmostad og Bjørke; 2016.

18. Thorkildsen IM. Voksnes holdninger - Vi tror ikke, vi ser ikke, og vi spør ikke. I: Mevik K, Lillevik OG, Edvardsen O, red. Vold mot barn: Teoretiske, juridiske og praktiske tilnærminger. 1. utg. Oslo: Gyldendal Norsk Forlag; 2016. s. 225-34. 